\title{
Superior Head of the Lateral Pterygoid Muscle Inserting in Asymptomatic Temporomandibular Joints
}

\author{
Inserción de la Cabeza Superior del Músculo Pterigoideo Lateral \\ en Articulaciones Temporomandibulares Asintomáticas
}

Horácio Pompei Filho*; Iván Suazo Galdames ${ }^{* *}$ \& Antonio Sergio Guimarães ${ }^{* * *}$

FILHO, P. H.; SUAZO, G. I. \& GUIMARÃES, A. S. Superior head of the lateral pterygoid muscle inserting in asymptomatic temporomandibular joints. Int. J. Odontostomat., 4(1):19-22, 2010.

SUMMARY: The constitution and shape of superior head of the lateral pterygoid muscle (SHLP) inserts remains a topic of interest in the literature. The purpose of this study was to analyze by magnetic resonance imaging (MRI) the temporomandibular joint (TMJ) of individuals without signs of temporomandibular dysfunction. One hundred seventy-eight MRI images of one hundred and three patients were utilized, and the surface and percentage of the SHLP insert into the articular disc and condilar process was determined. In women, the average insertion into the disc was found to be between 5.7-5.5mm (SD 1.5-1.3), corresponding to 69.8-70.7\% of the SHLP. In men, the average insertion into the disc was between $6.2-6.12 \mathrm{~mm}$ (SD 1.8-1.9), or 68.9-74.2\%. There were no differences in terms of the sex of the patients or the side of the joint. We found a significant percentage of SHLP fibers embedded in the disc of asymptomatic TMJs, and its role in the anterior disc displacement and the development of the temporomandibular dysfunction should be revised.

KEY WORDS: Temporomandibular joint; Lateral pterygoid muscle; Temporomandibular joint dysfunction; Articular disc; Anterior disc displacement.

\section{INTRODUCTION}

The lateral pterygoid muscle (LPM), which generates controversial discussions, has been traditionally described as a two-headed muscle with opposing action that plays a major role in the dynamics of the temporomandibular joint (TMJ) (Bertilsson \& Strom, 1995; Murray et al., 2001; Murray et al., 2004). However, recent studies indicate that their heads do not show a clear division (Usui et al., 2008; Pompei Filho et al., in Press), and is considered by some authors as a penniform muscle (El Haddioui et al., 2005; Desmons et al., 2007).

Tascaya-Yilmaz et al. (2005) have reported that the superior head of the lateral pterygoid muscle (SHLP) insert can be only be done on a disc or in the condilar process. According to Naohara (1989) disc insertion reaches $30 \%$ of the SHLP; Bittar et al. (1994) note that the percentage is $31 \%$, similar that reported by Naidoo \& Juniper (1997), who indicated that $29.5 \%$ of the SHLP fibers are inserted into the disc. Zhang et al. (1998) note that only $10 \%$ of the fibers reach the disc.

Against this background, this study aims to analyze through magnetic resonance imaging (MRI) the TMJ size and percentage of the insertion of SHLP in the articular disc in patients with temporomandibular dysfunction.

\section{MATERIAL AND METHOD}

A descriptive cross-study was designed based on imagery obtained from the central computerized tomography of Hospital Samaritano (CTCHS) de São Paulo, Brazil. The study had the approval of the hospital's ethics committee.

\footnotetext{
* Centro de Pós-Graduação / CPO São Leopoldo Mandic, Campinas, Brasil.

* Departamento de Ciencias Básicas Biomédicas, Universidad de Talca, Chile.

${ }^{* * *}$ Instituto da Cabeça, Universidade Federal de São Paulo, Brazil.
} 
Patients. This study involved 103 adult patients between 20 and 45 years old ( 71 women and 32 men) who came to CTCHS for MRI of TMJ between September 2007 and July 2008. Examinations were requested by different clinical services, and patients with a history of TMJ closed-lock, disc adherence, trauma study, or pre- and post-TMJ surgery assessments were excluded. The patients were informed of the nature of the study, and they agreed to the subsequent use of their images for these purposes.

Images. The MRI study of the TMJ were obtained with the patient in maximum aperture without pain, with sagittal standard corrected, and with the T1 protocol used for the anatomical study of the TMJ. Only those images that allowed viewing and defined the disc and SHLP completely were selected; 28 images were excluded (9 right side, 19 left side), and finally the sample had 178 images of 103 patients.

Image analysis. The selected images were processed using the MEVIS 2.9 software, where SHLP, the articular disc, and mandibular head were identified. The linear length of insertion of the SHLP in the disc and mandibular neck was determined, and the measurement was made with a guide line perpendicular to the orbitomeatal plane that hit the anterior edge of the disc (Fig. 1).

Statistical analysis. With the results of the insertion measurements of the SHLP in the disc and in the mandibular neck, the descriptive statistics of the sample were calculated. Differences in means by sex of the patient and the location of the joint were compared using the t-test for independent samples $(p<0.05)$.

Reliability. The reliability of the measurements of insertion of the SHLP in the disc and in the mandibular neck was analyzed using the remeasurement of a random sample ( $n=19$ cases), and expressed in terms of the intercorrelation coefficient (ICC).

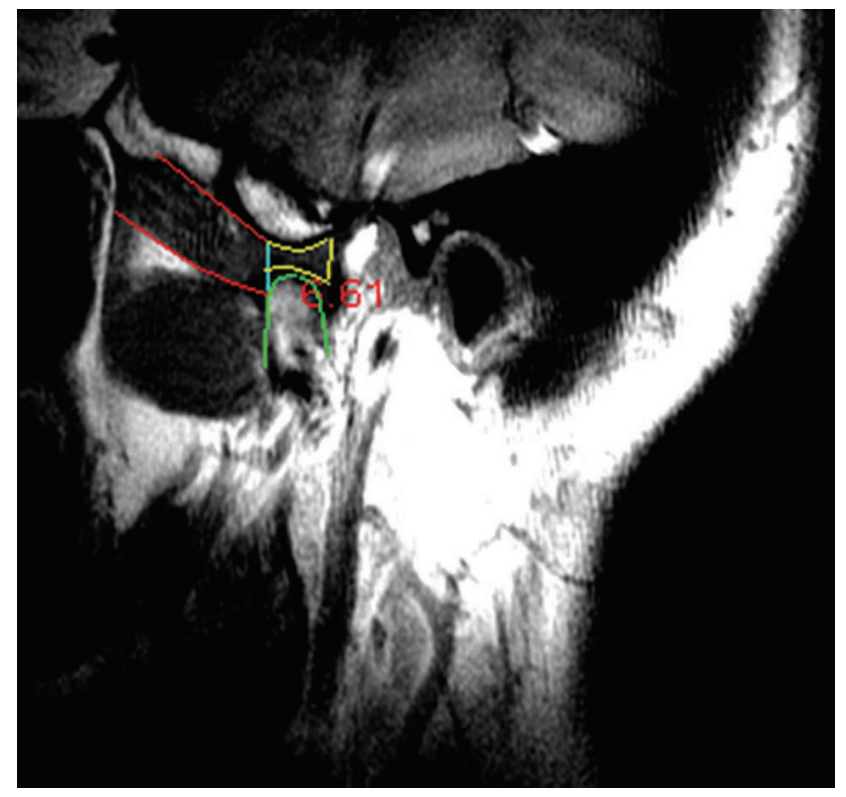

Fig. 1. Sagittal standard MRI of TMJ. Red: Bounded SHLP; Yellow: Articular disc; Green: Mandibular head; Blue: Perpendicular line to the orbitomeatal plane through the front surface of the disc. Measurement result $=6.61$.

\section{RESULTS}

The percentage of the SHLP insertion in the disc was between $69.8-68.94 \%$ (SD 15.61-16.55), whereas in the mandibular neck it was $30.11-31.05 \%$ (SD 17.18-16.35). Detailed measurements and their corresponding distributions are shown in Table I. No differences according to sex of the patient or the location of the joint were observed.

The measurements showed good reliability where the ICC for measuring the insertion of the SHLP in the condyle and in the articular disc were 0.89 and 0.95 , respectively.

Table I. Descriptive statistics of the insertion of the SHLP in the disc and the mandibular neck in the MRI of 178 TMJ cases. $\mathrm{SHLP}=$ Superior head of the lateral ptrygoid muscle; $\mathrm{AD}=$ Articular disc; $\mathrm{MH}=$ Mandibular head.

\begin{tabular}{cccccccccccccc}
\hline & \multicolumn{4}{c}{ Woman images $\mathbf{n = 1 3 1}$} & \multicolumn{4}{c}{ Men images $\mathbf{n = 4 7}$} \\
\cline { 2 - 15 } & \multicolumn{3}{c}{ Rith $\mathbf{n = 7 1}$} & \multicolumn{3}{c}{ Left $\mathbf{n = 6 0}$} & \multicolumn{3}{c}{ Right $\mathbf{n = 2 3}$} & \multicolumn{3}{c}{ Left $\mathbf{n = 2 4}$} \\
\cline { 2 - 15 } Mean & SHLP & AD & MH & SHLP & AD & MH & SHLP & AD & MH & SHLP & AD & MH \\
SD & 8.52 & 5.77 & 2.75 & 8.05 & 5.50 & 2.54 & 9.05 & 6.20 & 2.84 & 8.34 & 6.12 & 2.22 \\
\% & 2.41 & 1.53 & 1.69 & 2.12 & 1.3 & 1.82 & 2.04 & 1.87 & 1.58 & 2.26 & 1.98 & 1.49 \\
SD & 100 & 69.88 & 30.11 & 100 & 70.79 & 29.20 & 100 & 68.94 & 31.05 & 100 & 74.25 & 25.74 \\
N & 0 & 15.61 & 17.18 & 0 & 15.46 & 17.08 & 0 & 16.55 & 16.35 & 0 & 15.43 & 15.46 \\
\hline
\end{tabular}




\section{DISCUSSION}

The results of this study show that a large percentage of the SHLP fibers is inserted in the TMJ disc; between $69.8-68.94 \%$ of these values are higher than those reported in literature where most studies indicate rates that range 10-31\% (Bittar et al.; Naidoo \& Juniper; Naohara; Zhang et al.). No significant differences attributable to sex or age were found.

A higher level of integration of the SHLP in the disc can be involved in the development of anterior disc displacement and temporomandibular dysfunction. To Tanaka et al. (2007), LPM hyperactivity can cause progression of anterior disc displacement, while Taskaya-Yilmaz et al. indicate that this disc condition causes morphological changes in the SHLP associated with lower muscular activity. The assumption that anterior disc displacement is caused by the overactivity of the SHLP has justified the development of therapies that aim to block the activity of the muscle fibers (Bakke et al., 2005); however, the existing literature offers insufficient evidence to support this hypothesis. In this study, the high percentage of fibers embedded in the SHLP disc was found in individuals with no signs of temporomandibular dysfunction.

In conclusion, a significant percentage of SHLP fibers are embedded in the disc of the TMJ, but its role in the anterior disc displacement should be reviewed. Clinical studies are needed to establish the association between the percentage of the insertion of the SHLP and the status of anterior disc displacement.

FILHO, P. H.; SUAZO, G. I. \& GUIMARÃES, A. S. Inserción de la cabeza superior del músculo pterigoideo lateral en articulaciones temporomandibulares asintomáticas. Int. J. Odontostomat., 4(1):19-22, 2010.

RESUMEN: La constitución y la forma de inserción de la cabeza superior del músculo pterigoideo lateral (CSMPL) sigue siendo un tema de interés en la literatura. El objetivo de este estudio fue analizar mediante resonancia nuclear magnética (RNM) la articulación temporomandibular (ATM) de individuos sin signos de disfunción temporomandibular. Fueron utilizadas 178 imágenes de RNM pertenecientes a 103 pacientes. Se determinó la superficie y porcentaje de la inserción de la CSMPL en el disco y proceso condilar. En mujeres, la media de inserción en el disco estuvo entre 5,7-5,5 mm (SD 1,5$1,3)$ correspondiente al 69,8-70,7\% de la CSMPL. En hombres, la media de inserción en el disco estuvo entre 6,2-6,12mm (SD 1,8-1,9) correspondiente al 68,9-74,2\% de la CSMPL. No hubo diferencias en cuanto al sexo de los pacientes o lado de la articulación. Hemos encontrado un porcentaje significativo de las fibras de la CSMPL insertadas en el disco de ATMs asintomáticas, y su papel en el desplazamiento anterior del disco y el desarrollo de disfunción temporomandibular debe ser revisado.

PALABRAS CLAVE: Articulación temporomandibular; Músculo pterigoideo lateral; Disfunción de la articulación temporomandibular; Disco articular; Desplazamiento anterior del disco.

\section{REFERENCES}

Bakke, M.; Moller, E.; Werdelin, L. M.; Dalager, T.; Kitai, N. \& Kreiborg, S. Treatment of severe temporomandibular joint clicking with botulinum toxin in the lateral pterygoid muscle in two cases of anterior disc displacement. Oral Surg. Oral Med. Oral Pathol. Oral Radiol. Endod., 100:693-700, 2005.

Bertilsson, O. \& Strom, D. A literature survey of a hundred years of anatomic and functional lateral pterygoid muscle research. J. Orofac. Pain, 9:1723, 1995.

Bittar, G. T.; Bibb, C. A. \& Pullinger, A. G. Histologic characteristics of the lateral pterygoid muscle insertion to the temporomandibular joint. J. Orofac. Pain, 8:243-9, 1994.
Desmons, S.; Graux, F.; Atassi, M.; Libersa, P. \& Dupas, P. H. The lateral pterygoid muscle, a heterogeneous unit implicated in temporomandibular disorder: a literature review. Cranio, 25:283 -91, 2007.

El Haddioui, A.; Laison, F.; Zouaoui, A.; Bravetti, P. \& Gaudy, J. F. Functional anatomy of the human lateral pterygoid muscle. Surg. Radiol. Anat., 27:27186, 2005.

Pompei Filho, H.; Suazo, G. I.C. \& Guimaraes, A.S. Prevalence of the third head of the lateral pterygoid muscle a magnetic resonance image study. Int. $J$. Morph. In Press.

Murray, G. M.; Phanachet, I.; Uchida, S. \& Whittle, T. 
The role of the human lateral pterygoid muscle in the control of horizontal jaw movements. J. Orofac. Pain, 15:279-92; discussion 292-305, 2001.

Murray, G. M.; Phanachet, I.; Uchida, S. \& Whittle, T. The human lateral pterygoid muscle: a review of some experimental aspects and possible clinical relevance. Aust. Dent. J., 49:2-8, 2004.

Naidoo, L. C. \& Juniper, R. P. Morphometric analysis of the insertion of the upper head of the lateral pterygoid muscle. Oral Surg. Oral Med. Oral Pathol. Oral Radiol. Endod., 83:441-6, 1997.

Naohara, $\mathrm{H}$. The macroscopic and microscopic study of the human lateral pterygoid muscle. Tsurumi Shigaku, 15:1-26, 1989.

Tanaka, E.; Hirose, M.; Inubushi, T.; Koolstra, J. H.; van Eijden, T. M.; Suekawa, Y.; Fujita, R.; Tanaka, M. \& Tanne, K. Effect of hyperactivity of the lateral pterygoid muscle on the temporomandibular joint disk. J. Biomech. Eng., 129:890-7, 2007.

Taskaya-Yilmaz, N.; Ceylan, G.; Incesu, L. \& Muglali, $M$. () A possible etiology of the internal derangement of the temporomandibular joint based on the MRI observations of the lateral pterygoid muscle. Surg. Radiol. Anat., 27:19-24, 2005.

Usui, A.; Akita, K. \& Yamaguchi, K. ()An anatomic study of the divisions of the lateral pterygoid muscle based on the findings of the origins and insertions. Surg. Radiol. Anat., 30:327-33, 2008.

Zhang, L.; Sun, L. \& Ma, X. A macroscopic and microscopic study of the relationship between the superior lateral pterygoid muscle and the disc of the temporomandibular joint. Zhonghua Kou. Qiang. Yi. Xue. Za. Zhi., 33:267-9, 1998.
Correspondence to:

Antonio S. Guimarães

Instituto da Cabeça

Universidade Federal de São Paulo

Rua Visconde da Luz \#60/31

Zip Code: 04537070

São Paulo

BRAZIL

Email: asgatm@uol.com.br

Received: 30-10-2009

Accepted: 21-01-2010 